\title{
Sex Education and Teenage Pregnancy in the Niger Delta: Implications for Secondary School Biology Curriculum in Nigeria
}

\author{
Marie Onovroghene Salami, ${ }^{1, *}$ \\ ${ }^{1}$ Department of Science and Technology Education, Faculty of Education, Obafemi Awolowo University, Ile-Ife, \\ Nigeria \\ ${ }^{*}$ Correspondence: Department of Science and Technology Education, Faculty of Education, Obafemi Awolowo \\ University, Ile-Ife, Nigeria. E-mail: mariesalami56@yahoo.com
}

Received: February 5, $2015 \quad$ Accepted: April 3, $2015 \quad$ Online Published: May 12, 2015

doi:10.5430/wje.v5n3p73 URL: http://dx.doi.org/10.5430/wje.v5n3p73

\begin{abstract}
Previous studies show that when Nigerian adolescent girls, especially those in the Niger Delta, become pregnant they drop out of school and may never go back again but become low level labourers or miscreants to the society. This study investigated the extent of teenagers involvement in sex, pre-disposition of females to pregnancy in the Niger Delta of Nigeria, the level of readiness of parents to help their teenage daughters if they become pregnant, the level of sex education in secondary schools, the content and context of sex education in the Biology curriculum and how it is reflected in the National policy on education and also examined the need to review the policy vis-à-vis sex education. The study adopted a survey design using Likert-response questionnaires to elicit responses from students, parents, secondary school teenagers and Biology teachers. The results of the analysis using frequency counts, percentages, and analysis of variance (ANOVA) revealed that teenage pregnancy is on the increase in the Niger Delta, sex education is not given a place of priority in the Education National Policy, teachers shy away from teaching it in schools, parents do not support sex education in schools but there is an urgent need to incorporate it into the Biology curriculum.
\end{abstract}

Keywords: national policy on education; sex education; teenage pregnancy

\section{Introduction}

Teenage pregnancy and childbearing occurs in every society but varies from country to country and it was the focus of the 2013 World Population Day. This indicates that teenage pregnancy has global effects and implications which need the attention of every country. In Nigeria, studies show that the problems of teenage pregnancy affect the country's development. Education and practice bring about development. Nigerian teenage boys and girls need education for development.

The teenage years (12-18) are the years of adolescence when teenagers are easily excited sexually because of the biological changes in their bodies, including production of sex hormones. The teenage years are also the period when the average adolescent is in post- primary school in Nigeria. It is the period when the adolescent bubbles with a lot of energy and wants to be recognised or heard and feels he/she can handle problems all alone and may not need the advice of older persons. The teenage years are when adolescents are expected to be in secondary schools in preparation for tertiary education where they can acquire knowledge and skills for development. These days, adolescents develop biological maturity earlier than in the past generations although they often do not reach psychological maturity and economic independence until much later (Creatsas, 1993). Research has shown that many reasons are given for the occurrence of teenage pregnancy. The reasons include poverty, ignorance, inferiority complex, peer influence, among others. These reasons are in contrast with the prevalent myth in Britain where teenage girls believe that there are economic and social advantages in having a baby (Irvine, Bradley, Cupples and Boohan, 1997). According to Irvine et al, (1997) however, contrary to such speculation, several research studies reported that the majority of teenage pregnancies in Britain are unplanned and the outcomes for the mother and child in terms of life chances are negative.

Adolescence is a stage in the lives of young boys and girls where many of them have difficulties in adjusting to life and dealing with their sexuality. Jolley (2001) noted that there is a need for more information regarding safe sex 
which not only educate adolescents about how to avoid an unwanted pregnancy but also will prepare them to know how to be protected from sexually transmitted infections and HIV. In the Nigerian context, sex education is regarded as a taboo that should not be mentioned in the public. The little knowledge of sex education that a teenager is to acquire before marriage is expectedly given by the parent of the same sex. A survey of women and livelihood in the Niger Delta by Sofri (1987) revealed that unfortunately, most parents in Nigeria due to cultural and traditional norms find it difficult to engage or involve their children who are of adolescent age in sex and sexuality education. These cultural and traditional norms are so strong that the children may not be able to know the proper names of their sex reproductive organs. According to Ekeng, Ekanem and Esien (2014), this lack of knowledge is due to cultural inhibitions whereby the parents use coined words to refer to the male and female sex organs. Very often, the knowledge of the children about the utility of their sex organs is limited to urination. Hence, when their bodies begin to show sexual sensations at adolescence, the adolescents become confused and then dare to try to use it for sexual activities. In certain situations (Ekeng et al, 2014), adolescent girls may not be able to refuse sex.

Sex education before the attainment of puberty could equip boys and girls to develop the right attitude in adolescence that will equip them for challenges of growing up and becoming effective citizens that could be integrated into the society. This is clearly stated in the National Policy on Education (NPE, 2007) Section 1, sub-section 5 (Philosophy and Goals of Education in Nigeria), that Nigeria's philosophy of education is based on:

(a) the development of the individual into a sound and effective citizen;

(b) the full integration of the individual into the community; and

(c) the provision of equal access to educational opportunities for all citizens of the country at the primary, secondary and tertiary levels both inside and outside the formal school system (FGN, 2007).

Sex education is the acquisition of adequate information, forming right attitude and beliefs about sex, sexuality, sexual identity, relationship and intimacy. Among the many dramatic developmental events and changes surrounding puberty, the most challenging is the emerging sense of identity and the hormonal induced increase in sexual drive. Another challenge that is faced by the adolescent at this stage is the unfamiliar frequency of unpredictable and 'mysterious' subjective feelings, fantasies and impulses that accompany the phenomena of the changes. How then does the emerging Nigerian adolescent cope with the attendant myriads of problems associated with the period? Sex education in schools, in addition to what parents expectedly teach adolescents at home will go a long way in helping them to overcome the stress of the period. Unfortunately, the Nigerian biology curriculum does not contain any topic on sex education. Instead, the areas covered are on courtship behaviour in mammals and population and family planning (FGN, 2009.) The implication is that the Nigerian adolescent gathers information from peers and probably from mass media. Such information could be misleading to the adolescent. The need to help those who may drop out of school because of teenage pregnancy to go back to school and to educate those who are still in school on sex education is the focus of this study.

\section{Questions}

For the purpose of this study, the following questions were raised: Why do Nigerian adolescent boys and girls indulge in premarital sex? What chances have pregnant Nigerian teenage girls to go back to school after delivery? How much parental support do pregnant Nigerian teenage girls receive during pregnancy and after delivery? What is the attitude of students, teachers and parents towards sex education in Nigeria? How much of sex education do secondary school students receive in Biology classes in Nigeria?

The following objectives were generated from the above questions: to investigate why Nigerian teenage boys and girls indulge in premarital sex; assess the degree of support from parents to teenage girls during pregnancy and after delivery; examine the possibility of pregnant Nigerian teenage secondary school girls to go back to school after delivery; assess the degree of support from parents to pregnant teenage secondary school girls during pregnancy and after delivery; and compare the attitude of students, teachers and parents towards the inclusion of sex education in Nigerian secondary schools Biology curriculum.

\section{Methodology}

A Likert-scale type questionnaire was administered to 122 students, 80 teachers and 60 parents randomly selected from three randomly selected communities in Ethiope East, Uvwie and Sapele Local government areas of Delta State of Nigeria to elicit their responses for the study. The students' questionnaire contained 20 items, while that of the teachers and parents had 14 and 10 items respectively. The responses were given as strongly agree (SA), agree (A), 
disagree (D), and strongly disagree (SD) which were weighted as 4, 3, 2, 1 respectively. The responses were collated and analysed using frequency count, percentages, and ANOVA.

\section{Results and Discussion}

The results show that $0 \%$ of the female respondents claimed not to have had sex before, yet they agreed that teenage pregnancy is on the increase (84.43\%) and (81.15\%) agreed that more girls are dropping out of school as a result of pregnancy. Many discussions and researches have been carried out on teenage pregnancy in Nigeria and in other countries. Ayuba (2012) worked on the outcome of teenage pregnancy in the Niger delta of Nigeria and concluded that young maternal age at delivery has been proposed as risk factor for adverse pregnancy outcome. In addition, Ayuba (2012) said that teenage pregnancy can have serious physical consequences and teenage mothers are likely to be unmarried, poor, and remain uneducated. Oronsaye, Ogbeide and Unuigbe (1982) noted that with moral standards changing towards permissiveness in recent years and with a steady fall in the age of the menarche and an earlier sexual and physical maturity of the adolescent, an increase in teenage pregnancies is to be expected. Nigeria is no exception to this trend. They reported that majority of the pregnancies in their study occurred in students between the ages of 15 and 19 years who were in the first 3 years of secondary school. This seems to suggest that the responsible factor was inexperience in coping with the new-found independence from home and strict parental control, which going to school probably provides. Oronsaye et al (1982) suggested that stable homes in providing adequate parental care and education on sexuality and family life is indispensable in moulding the sexual behaviour of the adolescent. This primary role of the family should be reinforced at school by the inclusion of sex education in the biology curriculum. This supports the results of this study as shown in Table 5 where all the respondents, though with varied degree, supported the teaching of sex education in schools. By so doing, teenage pregnancy can be tackled by implementing proper strategies that will prevent teenagers from being pregnant (Sarantaki and Koutelekos, 2014).

Chapman, Werner and Ronald (2008) suggested that a positive youth development research and programming should include promoting healthy sexuality as an important developmental outcome for youth.

Young girls in the Niger delta have been lured and deceived to respond to the lust of thousands of oil workers. The result of which include rising incidence of female prostitution, teenage pregnancies and broken homes. According to the findings of Maliki (2014), effects and causes of teenage pregnancy include low socio-economic status, cultural factors, permissiveness of parents, drop in moral values and teenagers' sexual behaviour. The results of this study showed that teenage respondents disagreed that they could have sex because of money ( $48 \%$ ) though $74 \%$ of the male respondents agreed that they could have sex for money.

While a Tory member of parliament, Davis (2014) in the United Kingdom (UK) argued that sex education has increased teenage pregnancy, his attention was drawn to data from the office for National Statistics (ONS) released in February 2014, showing that the rate of teenage pregnancy is actually at its lowest since 1969. In contrast, teenage pregnancy has been on the increase in the Niger delta of Nigeria as indicated by the results of this study in Table 4 where $84.43 \%$ females and $15.55 \%$ of the males agreed that it has been on the increase. Also $81.15 \%$ of the females and $18.85 \%$ of the males indicated that more girls are dropping out of school than before. A suggestion was given during the UK parliamentary debate that parents should solely be responsible for providing their children's sex education. Such a situation will be inadequate in the Nigerian context because sex education given to children by their parents will not cover the area of anatomy and physiology of the adolescent which can be properly taught in schools. Meanwhile, a different view emerged in the United States (US, 2014) where eleven facts about sex education were given. These facts included that teens who receive a comprehensive education about sex are 50 percent less likely to have an unintended pregnancy than those who receive no sex education or receive sex education that are abstinence-only or contraception-only programmes. Another fact from the US was that almost 80 percent of parents support sex education that includes information about sexual orientation. It was also mentioned that more than 90 percent of parents of junior and high school students believe that it is important for sex education to be included in the curriculum. The aforementioned facts point to the importance of sex education in the school curriculum as it assists in exposing teenage boys and girls to the reproductive system. This helps them to know their body functions and why they should not get involved in sexual activities (Ekeng et al, 2014).

This study was interested in finding out why teenage pregnancy is getting more prevalent in the Niger Delta, the degree of support from parents to pregnant secondary school teenagers, the opportunity in getting back to school after delivery among teenage secondary school girls and the opinion of students, teachers and parents on the teaching of sex education in Nigerian secondary schools. The results from the study are as shown in the following tables: 
Table 1. Extent of Involvement in Sex

\begin{tabular}{llllcr}
\hline S/N & \multicolumn{1}{c}{ Item } & Response & \multicolumn{2}{c}{ Gender } & TOTAL \\
\cline { 3 - 5 } & & Categories & Female & Male & TOTA \\
\cline { 3 - 5 } 1. I have had sex at least once & No & $48(100 \%)$ & $67(90.5 \%)$ & $115(94.3 \%)$ \\
& & Yes & $0(0 \%)$ & $7(9.5 \%)$ & $7(5.3 \%)$ \\
\cline { 3 - 5 } & & & 48 & 74 & 122 \\
\hline
\end{tabular}

From Table 1, none of the girls responded to having had sex at least once while 7 boys representing $9.5 \%$ admitted to have had sex at least once.

Table 2. Reasons Why Teenage Boys and Girls Involve in Premarital Sex

\begin{tabular}{llllll}
\hline S/N & Items & Response & \multicolumn{2}{c}{ Gender } & Male \\
\cline { 3 - 4 } & & Categories & Female & TOTAL \\
\hline 1. & I have sex because my friends & No & $48(100 \%)$ & $73(98.6 \%)$ & $121(99.2 \%)$ \\
& have all tried it & Yes & $0(0 \%)$ & $1(1.4 \%)$ & $1(0.8 \%)$ \\
& Total & & 48 & 74 & 122 \\
2. & I have sex because of money & No & $48(100 \%)$ & $74(100 \%)$ & $122(100 \%)$ \\
& & Yes & $0(0 \%)$ & $0(0 \%)$ & $0(0 \%)$ \\
\hline
\end{tabular}

Table 2, shows only 1 out of the 7 boys that responded to having had sex at least once responded that he tried it because his friends had tried it. This thus shows that despite the inhibitions exercised by students in disclosing their sexual activities which is an aftermath of cultural values related to sanctity, there are other reasons why the students may engage in sex and sex activities. Neither the boys nor girls polled engage in sex for monetary purposes.

Inferences were made from the analysis of female students' responses to relevant items of the students' questionnaire since they are the most hit by unwanted pregnancies.

Table 3. The Possibility of Pregnant Teenage Girls to Go Back to School after Delivery

\begin{tabular}{|c|c|c|c|}
\hline \multirow[t]{2}{*}{$\mathbf{S} / \mathbf{N}$} & \multirow[t]{2}{*}{ Items } & \multicolumn{2}{|c|}{ Response Categories } \\
\hline & & Agree & Disagree \\
\hline 1. & $\begin{array}{l}\text { I hope to go back to school after delivery even if I get pregnant while in } \\
\text { school }\end{array}$ & $8(16.7 \%)$ & $40(83.3 \%)$ \\
\hline 2. & My baby may disturb my going back to school & $21(43.8 \%)$ & $27(56.2 \%)$ \\
\hline 3. & My parents will pay my school fees even after delivery & $5(10.42 \%)$ & $43(89.58 \%)$ \\
\hline 4. & I am shy so I will not go back to school after delivery & $19(39.58)$ & $29(60.42 \%)$ \\
\hline 5. & $\begin{array}{l}\text { My school mates may make fun of me about my pregnancy/baby, so I will not } \\
\text { go back to school after delivery }\end{array}$ & $25(52.08 \%)$ & $23(47.92 \%)$ \\
\hline 6. & My parents will disown me if they find out that I am pregnant & $35(72.92 \%)$ & $13(27.08 \%)$ \\
\hline 7. & $\begin{array}{l}\text { My parents will help me and take care of me even if they discover that I am } \\
\text { pregnant }\end{array}$ & $5(10.42 \%)$ & $43(89.58 \%)$ \\
\hline 8. & My parents will still sponsor my education even after the delivery of my baby & $5(10.42 \%)$ & $43(89.58 \%)$ \\
\hline
\end{tabular}

The responses above indicate that there are odds against teenage girls when they get pregnant and as such there are lean chances that they would go back to school.

Table 4. Degree of Parental Support to Pregnant Teenage School Girls during and After Delivery in the Niger Delta

\begin{tabular}{lllc}
\hline S/N & \multicolumn{1}{c}{ Items } & \multicolumn{2}{c}{ Response Categories } \\
\cline { 3 - 4 } & & Agree & Disagree \\
\hline 1. & $\begin{array}{l}\text { I will disown my teenage daughter if she becomes pregnant while in } \\
\text { school }\end{array}$ & $51(85 \%)$ \\
2. & $\begin{array}{l}\text { I will stop paying my teenage daughter's school fees if she becomes } \\
\text { pregnant while in school }\end{array}$ & $15(25 \%)$ & $45(75 \%)$ \\
3. & $\begin{array}{l}\text { No support will come from me to my daughter if she gets pregnant in } \\
\text { school }\end{array}$ & $12(20 \%)$ & $48(80 \%)$ \\
\hline
\end{tabular}


The responses above show that pregnant teenage school girls could enjoy a relatively high level of support from their parents during pregnancy and after delivery.

Table 5. Determine the Trend of Teenage Pregnancy in the Niger Delta

\begin{tabular}{llll}
\hline S/N & \multicolumn{1}{c}{ Items } & \multicolumn{2}{c}{ Response Categories } \\
\cline { 3 - 4 } & & Agree & Disagree \\
\hline 1. & $\begin{array}{l}\text { Many more girls have been getting pregnant in } \\
\text { school in the last three years }\end{array}$ & $103(84.43 \%)$ & $19(15.58 \%)$ \\
2. & $\begin{array}{l}\text { The number of girls who dropped out of school } \\
\text { as a result of pregnancy has increased }\end{array}$ & $99(81.15 \%)$ & $23(18.85 \%)$ \\
\hline
\end{tabular}

The results in Table 5 show that 103 representing $84.43 \%$ of the respondents perceived that many girls are getting pregnant in school in the last three years. In the same vein, 99 students $(81.15 \%)$ of the total student respondents agree that the number of girls who dropped out of school as a result of pregnancy has increased.

Table 6. Analysis of Variance of the Attitude of Students, Teachers and Parents towards the Inclusion of Sex Education in Nigerian Secondary Schools Biology

\begin{tabular}{lccccc}
\hline \multicolumn{5}{c}{ ANOVA } \\
\hline Source of Variation & Sum of Squares & df & Mean Square & F & Sig. \\
\hline Between Groups & 11.014 & 2 & 5.507 & 19.796 & .000 \\
Within Groups & 44.230 & 159 & .278 & & \\
Total & 55.244 & 161 & & & \\
\hline
\end{tabular}

Table 6 depicts that there is significant difference between the attitude of students, teachers and parents towards the teaching of sex education in Nigerian secondary schools $\{\mathrm{F}(2,159)=19.796, p<0.000)$. The descriptive statistics reveals that the means of students, parents and teachers' attitude are 2.91, 2.20 and, 3.18 respectively. In order to know which group of respondents support sex education in schools most, the means were subjected to multiple comparison. The result showed that the teachers gave the highest support followed by the students while the parents were the least. The parents' response might have been influenced by cultural norms as mentioned by Ekeng et al (2014).

Table 7. Multiple Comparisons

Attitude of Students, Parents and Teachers

Scheffe

\begin{tabular}{|c|c|c|c|c|c|}
\hline \multirow{2}{*}{$\begin{array}{l}\text { (I) Group } \\
\text { (J) Group }\end{array}$} & \multirow{2}{*}{$\begin{array}{c}\text { Mean Difference } \\
(\mathrm{I}-\mathrm{J})\end{array}$} & \multirow[b]{2}{*}{ Std. Error } & \multirow[b]{2}{*}{ Sig. } & \multicolumn{2}{|c|}{ 95\% Confidence Interval } \\
\hline & & & & Lower Bound & Upper Bound \\
\hline Students & $.71120^{*}$ & .12724 & .000 & .3968 & 1.0256 \\
\hline $\begin{array}{l}\text { Parents } \\
\text { Teachers }\end{array}$ & -.26380 & .12724 & .120 & -.5782 & .0506 \\
\hline Parents & $-.71120^{*}$ & .12724 & .000 & -1.0256 & -.3968 \\
\hline $\begin{array}{l}\text { Students } \\
\text { Teachers }\end{array}$ & $-.97500^{*}$ & .16679 & .000 & -1.3871 & -.5629 \\
\hline Teachers & .26380 & .12724 & .120 & -.0506 & .5782 \\
\hline $\begin{array}{l}\text { Students } \\
\text { Parents }\end{array}$ & $.97500^{*}$ & .16679 & .000 & .5629 & 1.3871 \\
\hline
\end{tabular}




\section{Conclusion}

It is concluded from the findings of this study that some Nigerian boys and girls indulge in premarital sex not for money but out of ignorance hence the occurrence of teenage pregnancy among them. This confirms the findings by Maliki (2014). Premarital sex is a taboo in the area studied, yet adolescent boys and girls indulge in it. The findings revealed that there is little hope that girls who get pregnant in school will go back after delivery. $83.3 \%$ of them claimed that they will not receive parental care if they become pregnant in school. This response contradicts the $80 \%$ of the parents respondents who agreed to support their daughters even if they get pregnant in school. The general situation must have informed the reason why there is a strong support from teachers, followed by students and lastly parents to include sex education in the Nigerian secondary school Biology curriculum. If the inclusion is not done with urgency, the implication is that more teenage girls are likely to become pregnant in school out of ignorance in the Niger Delta of Nigeria.

\section{Recommendation}

It is recommended based on the findings of the study that sex education should be included in the school curriculum. More girls should be encouraged to be in school because there is a disparity in the population of boys and girls in favour of the boys. Parents should assist in the sex education of their teenage children. The study was carried in the Niger Delta area of Nigeria. Similar studies could be carried out in other states of the Niger Delta and other parts of the country. There is the need to review the National Policy on Education and the Biology Curriculum to include sex education.

\section{References}

Ayuba, I. I., \& Gani, O. (2012). Outcome of Teenage Pregnancy in the Niger Delta of Nigeria. US National Library of Medicine, National Institute of Health. Ethiop J. Health Sci, 22(1), 45-50.

Chapman, E. N., Werner, W., \& Ronald, J. (2008). Adolescence. Fall, 43(171), 505.

Creastas, G. (1993). Sexual Activity and Contraception during Adolescence. Current Opinion in Obstetrics and Gynaecology, 5, 774-783.

Davies, P. (2014). The Independent. Tory Philip Davies' Argument on Teenage Pregnancy. Retrieved 25/10/2014 from http://www.independent.co.uk/news/uk/politics/tory-mp-philip-davies...

Ekeng, N. E., Ekanem, S. A., \& Esien, O. E. (2014). Teenage Pregnancy and Education in Nigeria: A Philo-Sociological Management Strategy. Journal of Educational and Social Research, 4(3), 41-47.

Federal Government of Nigeria (2009). Senior Secondary Education Biology Curriculum for Senior Secondary Schools 1-3. Abuja, Nigeria, Nigerian Educational Research and Development Council.

Federal Republic of Nigeria (2007). National Policy on Education. Lagos Nigeria: NERDC Press.

Irvine, H., Bradley, T., Cupples, M., \& Boohan, M. (1997). The Implication of Teenage Pregnancy and Motherhood for Primary Health Care: Unresolved Issues. British Journal of General Practice, 47, 323-326.

Jolley, S. (2001). Promoting teenage sexual health: An investigation into the knowledge, activities and perceptions of gynaecology nurses. Journal of Advanced Nursing, 36(2), 246-255. http://dx.doi.org/10.1046/j.1365-2648.2001.01965.x

Maliki, A. E. (2014). The effect of teenage pregnancy on adolescents in Amasoma community of southern Ijaw Local Government Area of Bayelsa State. Sian Social Science, 8(1), 62-66.

Oronsaye, A. U., Ogbeide, O., \& Unuigbe, E. (1982). Pregnancy among school girls in Nigeria. International Federation of Gynaecology and Obstetrics, 20, 409-412. http://dx.doi.org/10.1016/0020-7292(82)90201-6

Sarantaki, A., \& Koutelekos, I. (2014). Teenage pregnancy. Health Science Journal, Issue 2. Retrieved from http://www.hsj.gr

Sofri, J. P. (1987). Survey on women and livelihoods in the Niger delta: An overview of women's economic activities in oil producing communities in Akwa Ibom, Bayelsa and Rivers states. Retrieved 01/08/2014 from www.cddwestafrca.org/.../41-on-women-livelihoods-in-the-niger-delta- cached-similar

US (2014). Eleven facts about sex education in the US. Retrieved 25/10/2015 from http://www.dosomething.org/actnow/tipsandtools/facts-about-sex-education-us-o 